\title{
A Comparative Study on the Behavior of Permeable Concrete by Partial Replacement of Cement with Black Cotton Soil
}

\author{
George Thayil ${ }^{1}$, Aniruddh Palande ${ }^{2}$, Prashant Mukeri ${ }^{3}$, Dhiraj Lanjewar ${ }^{4}$, Mr. Naveen Hanchinahal ${ }^{5}$ \\ ${ }^{1234}$ UG Students, Department of Civil Engineering, St John College of Engineering \& Management, Palghar \\ ${ }^{5}$ Assistant Professor, Department of Civil Engineering, St John College of Engineering \& Management, Palghar
}

Received on: 03 May, 2021, Revised on: 30 May, 2021, Published on: 1 June, 2021

\begin{abstract}
Permeable concrete is a type of concrete which allows water to pass through it's pores which prevents stagnation of water on pavements made by this concrete. This type of concrete possesses lower strength compared to other types of concrete making it unsuitable to support heavy loads. Various materials and admixtures have been partially replaced with cement in differing proportions to it's concrete mix design in an attempt to bring its compressive strength closer to that of conventional concrete. The purpose of this study is to highlight the changes in filtration rate, density and compressive strength of permeable concrete when it's cement proportion is partially replaced with that of black cotton soil.
\end{abstract}

Keywords: Effects, Black Cotton Soil, Proportions, Pervious Concrete

\section{I-INTRODUCTION}

$\mathbf{P}$ ermeable concrete is generally used in locations which are prone to water stagnation as it easily drains off all the water or any fluid poured on it's surface. Conventional road pavements with poor or clogged drainage system can result in water to be stagnant on it's surface since it's porosity is too low for water to pass through. The current research stands lacking since no significant breakthrough has been achieved in the pursuit of making the concrete as strong as conventional concrete of similar grade. Concrete is also asubstance which is man-made and therefore does not blend well the environment. This study is an effort to find balance between nature and infrastructure, helping people in areas prone to water logging to have a safer commute all the while minimizing the damage done to nature. The goal therefore is to use soil as an alternative to any other material used along with cement in permeable concrete. A comparative study was carried out and the results were evaluated to determine the behavior of permeable concrete and also to ascertain the practical applicability of the which were permeable in nature to find the optimum balance of several factors such as filtration rate, density and compressive strength of concrete. following study.

An intensive work was carried out casting and testing several concrete cubes cubes which were permeable in nature to find the optimum balance of several factors such as filtration rate, density and compressive strength of concrete respectively..

Pervious concrete which is also known as the no-fines, porous, gap-graded, and permeable concrete and enhance porosity concrete has been found to be a reliable storm water management tool. Black cotton soils are inorganic clays of medium to high compressibility and form a major soil group in India. They are characterized by high shrinkage and swelling properties. The black cotton soils is very hard when dry, but loses its strength completely when in wet condition. It is rich in magnesium, potassium, calcium carbonate and lime but poor in nitrogen and phosphorus. . The primary aim is to highlight the changes in filtration rate density and 


\section{International Journal of Innovations in Engineering and Science, www.ijies.net}

compressive strength of permeable concrete when its cement proportion is partially replaced with that of black cotton soil.

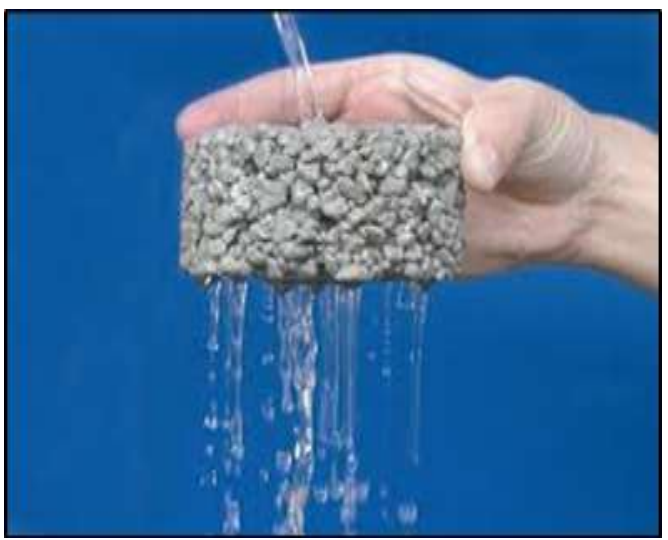

Fig no 1-Pervious concrete

\section{II-OBJECTIVES}

- To study the basic materials which are used in pervious concrete.

- To study the tests performed on pervious concrete as well as the materials used in it.

- To use black cotton soil by replacing it with cement.

- To check the Engineering properties of pervious concrete with black cotton soil partially replaced. (Compressive test, etc.)

- To find out the mechanical properties of pervious concrete mixed with black cotton soil and to compare it with the normal pervious concrete.

\section{III- MATERIALS AND TESTS}

For current project work various materials like Coarse aggregate and black cotton soil are collected. We conducted various tests on the above mentioned materials in laboratory.

\subsection{CEMENT}

cement OPC 43 procured from single source was used . Physical properties of which are tested in the laboratory and tabulated in Table 1.

Table 1-Physical properties of cement

\begin{tabular}{|c|c|c|}
\hline Properties & $\begin{array}{c}\text { Value } \\
\text { Obtained }\end{array}$ & IS-Code used \\
\hline $\begin{array}{c}\text { Standard consistency } \\
\text { of cement }\end{array}$ & $31 \%$ & $4031-4-1988$ \\
\hline Initial setting time & $30 \mathrm{~min}$ & $4031-5-1988$ \\
\hline Final setting time & $10 \mathrm{hrs}$ & $4031-5-1988$ \\
\hline Specific gravity & $3.15 \mathrm{~g} / \mathrm{cc}$ & $4031-11-1988$ \\
\hline
\end{tabular}

\subsection{Coarse Aggregate}

Coarse aggregate having nominal size $20 \mathrm{~mm}$ were used and different taste were performed and the result are tabulated as below.

Table 2: Physical properties of coarse aggregates

\begin{tabular}{|c|c|c|}
\hline Properties & $\begin{array}{c}\text { Value } \\
\text { obtained }\end{array}$ & IS-Code \\
\hline Specific gravity & 2.72 & $2386-3-1963$ \\
\hline $\begin{array}{c}\text { Fineness } \\
\text { modulus }\end{array}$ & 7.1 & $383: 1970$ \\
\hline Water absorption & $1.82 \%$ & $2386-3-1963$ \\
\hline
\end{tabular}

\subsection{Black Cotton Soil}

Good quality black cotton soil was used. The different tests for physical properties of black cotton soil are carried out in the laboratory and results aret tabulated.

Table 3- Physical properties of black cotton soil

\begin{tabular}{|c|r|c|}
\hline Properties & $\begin{array}{c}\text { Value } \\
\text { Obtained }\end{array}$ & IS-Code \\
\hline Specific gravity & 2.62 & $2720-3-1980$ \\
\hline Moisture content & $32 \%$ & $2720-2-1973$ \\
\hline Permeability & $4.84 \times 10^{-4} \mathrm{~cm} / \mathrm{sec}$ & $2720-17-1986$ \\
\hline Dry density & $1.31 \mathrm{~g} / \mathrm{cc}$ & $2720-7-1980$ \\
\hline
\end{tabular}

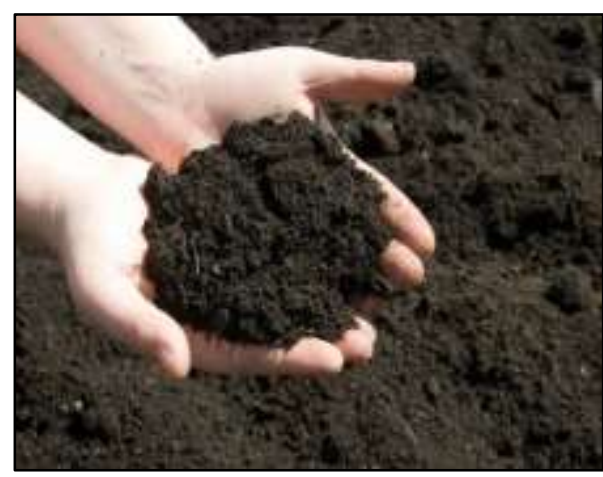

Fig 2-Black Cotton soil

\section{IV- EXPERIMENTAL WORK}

We have made an attempt to design permeable concrete of grade M25. The mix design has been carried out by using IS10262-2019 for the material details specified. The investigation was done by taking Cement $=1.2 \mathrm{Kg}$, Aggregates $=6.3 \mathrm{Kg}$, Water $=0.6 \mathrm{Kg}$ having different black cotton soil proportions by replacing cement with 5\% $10 \%$ $15 \% 20 \% 25 \% 30 \%$ of Black cotton soil in concrete mix.

One set of test cubes comprised of 3 concrete cubes and a total of 14 sets of cubes were cast. An average value was derived based on the various tests performed on the cubes. 


\section{International Journal of Innovations in Engineering and Science, www.ijies.net}

The first set of cubes were normal concrete cubes, the mix design consisting of cement and coarse aggregate of size $20 \mathrm{~mm}$. All the other sets of cubes consisted of cement, coarse aggregate $(20 \mathrm{~mm})$ and black cotton soil in the following proportions $-5 \%, 10 \%, 15 \%, 20 \%, 25 \%$ and $30 \%$. The total number of 42 cubs are casted. Casting and curing of cubes are done as per the standard procedure. After curing for 7 days and 28 days, we have performed compressive strength test, Density determination test, Filtration test, on concrete cubes.

Table 4- The experimental work for M25

\begin{tabular}{|c|c|c|c|}
\hline Sr.no & $\begin{array}{c}\text { Dimensions } \\
(\mathbf{m m})\end{array}$ & $\begin{array}{c}\text { Soil replaced } \\
(\%)\end{array}$ & $\begin{array}{c}\text { No. Of cubes } \\
\text { casted }\end{array}$ \\
\hline 1 & $150 * 150 * 150$ & $0 \%$ & 6 \\
\hline 2 & $150 * 150 * 150$ & $5 \%$ & 6 \\
\hline 3 & $150 * 150 * 150$ & $10 \%$ & 6 \\
\hline 4 & $150 * 150 * 150$ & $15 \%$ & 6 \\
\hline 5 & $150 * 150 * 150$ & $20 \%$ & 6 \\
\hline 6 & $150 * 150 * 150$ & $25 \%$ & 6 \\
\hline 7 & $150 * 150 * 150$ & $30 \%$ & 6 \\
\hline
\end{tabular}

\section{V- RESULTS}

Samples were tested after 28days and all the data and results are given in charts. The test result obtained from Compressive strength test and filtration test for concrete are analyzed graphically. In this section, average compressive strength for 28 days of concrete have been compared between pervious concrete and concrete mixed with black cotton soil. Similarly, the procedure was carried out for density determination of concrete.

\subsection{Compressive Strength}

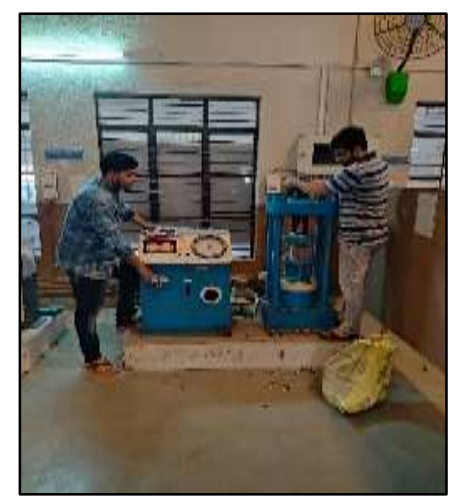

Fig 3-Compressive testing of cubes
Compressive Strength is defined as resistance of concrete to axial loading. Cubes were placed in Compressive Testing Machine (CTM), and load was applied. The readings were recorded upto final crack of the cube and compressive strength was calculated. The results of Compressive strength are shown in Table. Calculations: Compressive Strength $=$ Maximum load $/$ Cross Sectional Area $=$ P/A

\begin{tabular}{|c|c|c|c|}
\hline \multicolumn{4}{|c|}{ Table 5-Compressive strength of Concrete } \\
\hline $\begin{array}{c}\text { Sr } \\
\text {.no }\end{array}$ & $\begin{array}{c}\text { Black } \\
\text { cotton } \\
\text { soil (\%) }\end{array}$ & $\begin{array}{c}\text { w/c } \\
\text { ratio }\end{array}$ & $\begin{array}{c}\mathbf{2 8} \text { days } \\
\left(\mathbf{N} / \mathbf{m m}^{2}\right)\end{array}$ \\
\hline 1. & $0 \%$ & 0.4 & 10.56 \\
\hline 2. & $5 \%$ & 0.4 & 10.41 \\
\hline 3. & $10 \%$ & 0.4 & 9.84 \\
\hline 4. & $15 \%$ & 0.4 & 9.62 \\
\hline 5. & $20 \%$ & 0.4 & 8.44 \\
\hline 6. & $25 \%$ & 0.4 & 7.39 \\
\hline 7. & $30 \%$ & 0.4 & 6.82 \\
\hline
\end{tabular}

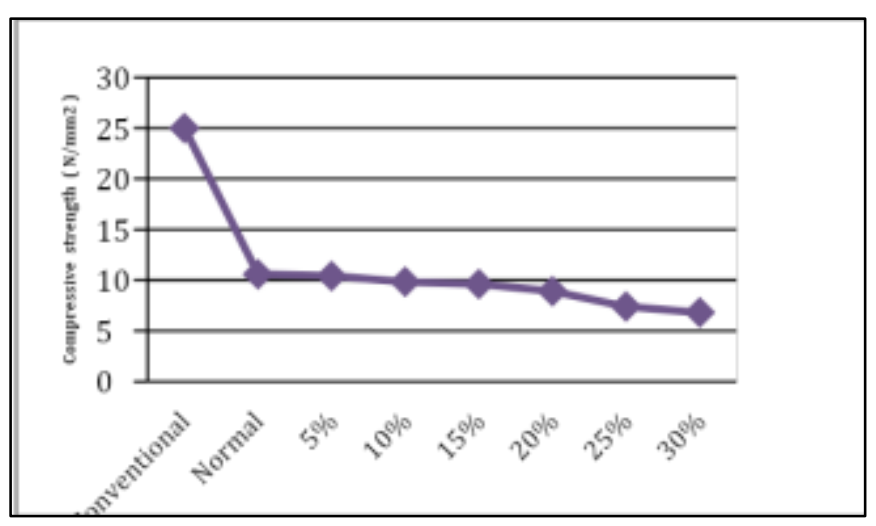

Fig 4- Graph showing variation of compressive strength at varying percentages of black cotton soil

The compressive strength test was conducted on the cubes with varying black cotton soil content $(0 \%, 5 \%, 10 \%, 15 \%$, $20 \%, 25 \%, 30 \%)$. From the graph that shows the variation of compressive strength of concrete at varying percentage of black cotton soil, it was found that compressive strength of concrete decreases with an increase in black cotton soil.

\subsection{Filtration Test}

The test involving filtration was carried out by pouring water over the cubes and using a stop watch to detemine the time in which water filtered out of the cubes. The filtration rate was calculated in liters/min. 


\section{International Journal of Innovations in Engineering and Science, www.ijies.net}

Table 6-Filteration rate of Concrete

\begin{tabular}{|c|c|c|}
\hline Sr.no & $\begin{array}{c}\text { Black cotton soil } \\
(\%)\end{array}$ & $\begin{array}{c}\text { 28 days } \\
\text { Filteration } \\
\text { rate(l/min) }\end{array}$ \\
\hline 1. & $0 \%$ & 1.45 \\
\hline 2. & $5 \%$ & 1.42 \\
\hline 3. & $10 \%$ & 1.41 \\
\hline 4. & $15 \%$ & 1.63 \\
\hline 5. & $20 \%$ & 1.83 \\
\hline 6. & $25 \%$ & 1.93 \\
\hline 7. & $30 \%$ & 1.98 \\
\hline
\end{tabular}

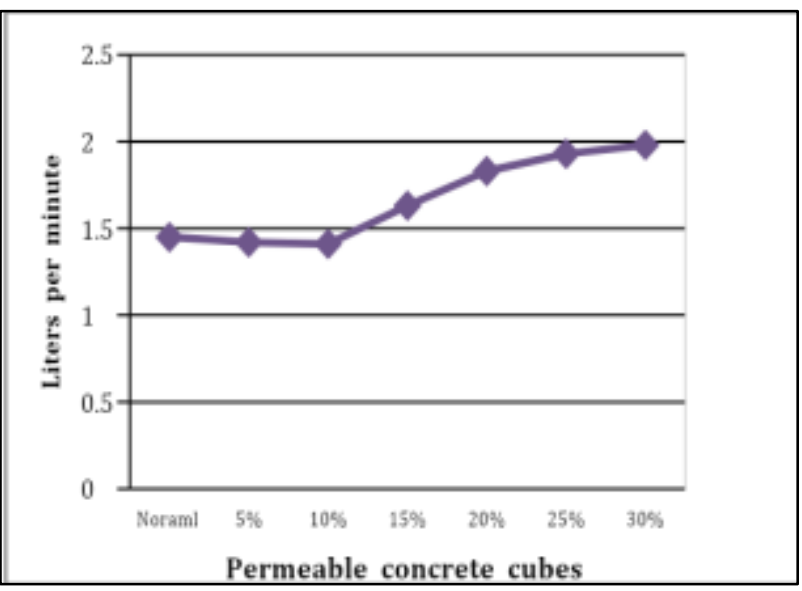

Fig 5 -: Graph showing filtration rate with varying black cotton soil

\subsection{Density Determination}

After the concrete cubes had dried, it was weighed using a weighing machine and later it's dimensions were noted. Using the formula for density calculation - mass/volume, the density of the cubes were determine.

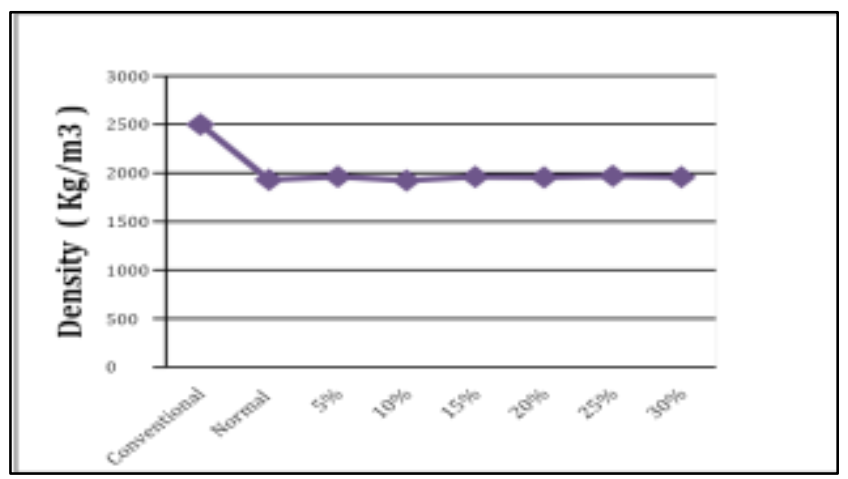

Fig 6- Graph showing Density of pervious concrete varying with black cotton soil

\section{VI- CONCLUSIONS}

As per the results of the study conducted, the findings of our research suggests that an increase in the proportion of black cotton soil shows significant increase in the rate of filtration.

The nature of permeable concrete cubes enables it to have lower density as compared to conventional concrete cubes of the same grade and therefore will have less burden on the underlying soil strata.

The compressive test of the cubes showed a considerable decline in strength as compared to conventional concrete cubes of same grade and further decline as more soil was added to the mix.

For practical purposes it can be suggested that this type of concrete be used in areas where low compressive stresses are imposed on concrete and where a greater filtration rate is required.

\section{REFERENCES}

[1] T Ahmed, S Hoque. Study on pervious concrete pavement mix designs; November 2019.

[2] Chao-Wei Tang, Chiu-Kuei Cheng, Ching-Yuan Tsai. Mechanical Properties of High-Performance Pervious Concrete; August 2019.

[3] Dr.G.Lavanyal S.Kausalya Devi, M.Kayalvizhi, T.Nithya, R.Ramkumar. Study on the properties of Top Mix Concrete Pavement; SSRG International Journal of Civil Engineering (SSRG-IJCE) - Special Issue ICRTETM, March 2019.

[4] F. Costa, A. Lorenzi, L. Haselbach, L. Filho. Best practices for pervious concrete mix design and laboratory tests; October 2018.

[5] Satish kumar, Dr.Devinder Sharma, Er. Neeraj Kumar. A Review paper on permeable concrete as a road pavement; International Research Journal of Engineering and Technology (IRJET), Volume: 04 Issue: December 2017.

[6] Bhuvanesh Gawad, Swati Dhurve, Hitesh Vanmali, Mayuresh Patil, "Study of Soil Biotechnology for Waste Water Treatment" SSRG International Journal of Civil Engineering 7.3 (2020): 8-12.

[7] Dev Pratap Mani Tripathi, S. M. Ashraf Hussain, PraneetMadhav. An Experimental Study on Pervious Concrete; International Journal of Engineering Research \& Technology (IJERT) Vol. 6 Issue 12, December - 2017. 
Vol. 6, No. 5, 2021, PP. 05 - 09

\section{International Journal of Innovations in Engineering and Science, www.ijies.net}

[8] Suraj F. Valvi, Anil P. Thoke, Abhijit A. Gawande, Manoj B. Godse, Prof .D.D Shelke. Use of pervious concrete in road pavement; International Journal of Advanced Research in Science and Engineering, Vol. No.6 Issue No.3, March 2017.

[9] Bhuvanesh Gawad, Swati Dhurve, "Strutural Assessment of old Building", Journal of Environmental Science, Computer Science and Engineering \& Technology 6(4): September 2017, Pages 466-478.

[10] AlessendraBonicelli, Gilberto Arguelles, Luis Gulliermo, Fuentes Pumarejo. Improving Pervious Concrete Pavements for Achieving More Sustainable Urban Roads; 2016.

[11] Bhuvanesh Gawad, Swati Dhurve, "Planning and designing of Soil Biotechnology Plant for the locality", International Journal of Innovative Research in science, Engineering and Technology Volume 9, 05 May 2020, Pages 3409-3415.

[12] Yail Kim, Adel Gaddafi, Isamu Yoshitake. Permeable concrete mixed with various admixtures; June 2016.

[13] John Tristan Kevern. Advancements in pervious concrete technology; Iowa State University, 2008.

[14] Bhuvanesh Gawad, "Concrete Mix Proportioning: A Short Note", Journal of Environmental Science, Computer Science and Engineering \& Technology 5(3): June 2016, Pages 262-266. 